\title{
The Impact of the Board of Directors Characteristics on the Risk of IPO Earnings Forecasts Errors
}

\author{
Abdulaziz Mohammed Alsahlawi ${ }^{1} \&$ Mohammed Abdullah Ammer ${ }^{1}$ \\ ${ }^{1}$ Department of Finance, School of Business, King Faisal University, Al-Hasa, Saudi Arabia \\ Correspondence: Abdulaziz Mohammed Alsahlawi, Department of Finance, School of Business, King Faisal \\ University, Al-Hasa, Saudi Arabia. E-mail: amalsahlawi@kfu.edu.sa
}

$\begin{array}{lc}\text { Received: August 5, } 2019 & \text { Accepted: August 26, } 2019 \quad \text { Online Published: October 24, } 2019 \\ \text { doi:10.5539/ass.v15n11p75 } & \text { URL: https://doi.org/10.5539/ass.v15n11p75 }\end{array}$

\begin{abstract}
This paper aimed to investigate the effect of corporate governance mechanism on the risk of IPO earnings forecasts errors. It focuses on the relationship between the board of directors characteristics and the risk of earnings forecasts errors. Required data was gathered from 190 Malaysian IPO prospectuses for the year 2002 to 2012, after which data was analyzed using ordinary least squares (OLS) regression. Based on the obtained findings, the earnings forecasts of Malaysian IPO reflected a pessimistic picture with unsatisfactory percentage of accuracy. In particular, the findings of multiple regression analysis of the relationships between the size, independence and CEO duality of the board of directors, and the risk of earnings forecasts errors were negative and insignificant. The study findings have several implications for relevant individuals, including regulators, investors, financial analysts and financial statements users.
\end{abstract}

Keywords: corporate governance, board of directors, earnings forecasts accuracy, IPOs

\section{Introduction}

The IPO prospectus contains a huge amount of significant information, one of which is the management earnings forecasts figure and its quality reflected by its accuracy, and this has garnered increasing research interest (Hutton \& Stocken, 2010). The issuance of IPO earnings forecast represents the promise of management that IPO company will provide a specific future income at the end of the IPO year to the shareholders (Hutagaol et al., 2012). Capital markets participants are largely dependent on the information flow stability for the risk evaluation and consideration of future prospects upon which the company equity can be evaluated (Foerster et al., 2013). Nevertheless, readily accessible financial information on IPO company is not as available compared to that on a listed company. In other words, IPO forms have to deal with considerable information asymmetry between shareholders and future investors (Guo et al., 2004; Bédard et al., 2008).

Consequently, most investors do not have access to sufficient information for the evaluation of the value of the reporting system of the IPO firm and thus, they take recourse in examining quality of factors including corporate governance structure, as these contribute to establishing the earnings reporting system credibility (Siagian \& Tresnaningsih, 2011). According to Chapple et al. (2018), there is a significant influence of corporate governance on management earnings forecast behavior, while other studies of the same caliber (e.g., Karamanou \& Vafeas, 2005; Mnif, 2010; Ahmad-Zaluki \& Wan-Hussin, 2010) indicated that well-structured corporate governance mechanisms, like the board of directors, can signal the financial information quality and credibility and this includes earnings forecasts.

In the same line of argument, errors in earnings forecasts have a likelihood of mitigating the reported earnings quality, their value upon which investment decisions are made and the investor confidence on the financial reports. But management earnings forecasts that are controlled through monitoring systems generate more reliable and quality earnings forecasts. More specifically, as internal corporate governance mechanisms, board of directors are in a good position to take on an effective monitoring role of keeping the management interests consistent with those of shareholders, lessening the opportunistic behavior of the former and in effect, improving the quality of the IPO earnings forecasts.

The present study has theoretical and practical contributions in the several ways. The first contribution relates to the increasing recognition of the management earnings forecasts relevance as evidenced by their inclusion in the IPO companies prospectuses - however, studies addressing them are still few and far between (Gounopoulos, 
2011). This necessitates the examination of its value relevance in present studies (Hartnett, 2010).

The second contribution relates to the fact that notwithstanding the information asymmetry issues and the agency problem that are rampant in IPO markets that can be addressed through monitoring mechanisms, studies dedicated to examining the effect of such mechanisms, like the board of directors, on the accuracy of IPO earnings forecasts are still lacking, and those that have been conducted have a general viewpoint (e.g., Ahmad-Zaluki \& Wan-Hussin, 2010; Cormier et al., 2014).

Added to the above contributions, empirical evidence and theoretical explanations on the corporate governance and company-specific characteristics relationship with IPO earnings forecasts accuracy have reported inconclusive findings (e.g., Yang \& Kao, 2007; Bédard et al., 2008; Mnif, 2010; Ahmad-Zaluki \& Wan-Hussin, 2010; Ammer \& Alsahlawi, 2019). Prior studies on the structure of board of directors failed to provide a complete perception of the board of directors as the primary responsible mechanism to enhance the earnings forecasts of the firms. Therefore, this study is an attempt to extend and support prior studies' findings and explanations (Ahmad-Zaluki \& Wan Hussin, 2010; Bédard et al., 2008; Ammer \& Ahmad-Zaluki, 2017) on the topic, as it furnishes evidence on the influence of the board of directors characteristics on the accuracy of management earnings forecasts.

This study employed the absolute forecast error to represent the accuracy of IPO management earnings forecasts and according to the obtained results, the level of accuracy of earnings forecasts in the IPO prospectuses of the Malaysian firms are still weak and unsatisfactory for the years 2002 to 2012. This shows that the IPOs management have to try their best at providing accurate earnings forecasts. The study findings also supported negative and insignificant effects of both board size and CEO duality on earnings forecasts errors. With regards to board independence, the results also indicated a negative but insignificant relationship to earnings forecast errors, which partially supports the argument that independent directors function towards increasing the accuracy level.

For smooth presentation, this paper is organized in the following order with their contents; in Section 2, review of relevant studies with their findings are conducted and used for hypotheses formulation. Section 3 contains the details of the study sample, methodology and the underpinning models and Section 4 presents the empirical findings from the analysis of data. Lastly, Section 5 concludes the paper.

\section{Literature Review and Hypotheses Development}

This part of the paper provides a review of the internal mechanism attributes (board of directors specifically) and their role in IPOs as supported by Certo et al. (2001) and Filatotchev and Bishop (2002).

\subsection{Board Size and Accuracy of IPO Management Earnings Forecasts}

According to Karamanou and Vafeas (2005), firms with smaller-sized boards report conservative earnings forecasts compared to those with larger-sized boards. Board size also has a significant impact on the unexpected financial statement frauds, which showed that large-sized boards increase the possibility of a fraudulent financial statement (Beasley, 1996). Moreover, in too large boards, establishing harmony and processing issues for handling becomes challenging, which could lead to ineffective board attempt to monitor functions (Abdul Rahman \& Ali, 2006). Similarly, Mnif (2010) revealed that IPO companies having large-sized boards may often disclose optimistic earnings forecasts that are in actuality inaccurate and thus, this study formulates the following hypothesis for testing;

H1: Board size is negatively associated with the accuracy of IPO management earnings forecasts (i.e. positively with the earnings forecasts errors).

\subsection{Board Independence and Accuracy of IPO Management Earnings Forecasts}

Board independence, in light of its relationship with quality of earnings forecasts was examined by prior studies such as, Karamanou and Vafeas (2005) and Ajinkya et al. (2005) and their findings supported a positive relationship between the two variables. Meanwhile in Mnif's (2010) study, the author reported that IPO firms are highly expected to present more conservative and accurate earnings forecasts when the members of their board of directors are independent. It can be logically stated that with the higher percentage of independent directors on the board, the accuracy of management earnings forecasts will also be higher.

In the same line of study, Beasley (1996) reported a negative relationship between external directors and cases of fraudulent financial statements while Klein (2002), Xie et al. (2003) and Saleh et al. (2007) revealed that external directors negatively relate to the earnings management practices. Also, the gap between unaudited earnings and actual earnings was found to be less for firms with independent board of directors, which means 
firms with effective governance report accurate earnings and as such, this study proposes the following hypothesis for testing;

H2: Board independence is positively associated with the accuracy of management earnings forecasts (i.e. negatively with the earnings forecasts errors).

\subsection{Board CEO Duality and Accuracy of IPO Management Earnings Forecasts}

The CEO and chairman of the board separation has been stressed on in the Malaysian MCCG 2000 because if the board chairman takes parts in executive operations, this will lead to decisions favoring the executive and thus, mitigating the board's oversight function, and ultimately decreasing the earnings forecasts credibility (Yang \& Koa, 2007). Moreover, CEO duality was found to have a positive relationship with earnings management practices in Saleh et al.'s (2005) study, and Abbott et al. (2000) supported a positive relationship between CEO duality and the possibility of aggressive reporting/fraud among companies. Therefore, this study formulated the following hypothesis for testing;

H3: Board-CEO duality is negatively related with the accuracy of management earnings forecasts (i.e. positively with the earnings forecasts errors).

Furthermore, prior studies have examined control variables in examining the above relationships and they found ownership structure (management ownership) to be related with the quality of earnings in the East Asian firms (e.g., Fan \& Wong, 2002). In East Asia, concentrated ownership generates agency conflicts between external investors and controlling shareholders and to this end, Jensen and Meckling's (1976) agency theory posits that agency costs are related to ownership of management function.

Reviewed literature (Jog \& McConomy, 2003; Firth et al., 2012) shows that underwriter's reputation and auditor quality have also been considered as control variables and thus, this study follows the same. According to Aharony et al. (1993), reputable auditors and underwriters are more incentivized to provide quality and accurate IPOs information to steer clear from facing litigation and reputation loss. On the whole, high-quality underwriter and auditor would work on preserving their reputation and thus, they will accurately prepare IPO prospectuses to do so.

Lastly, there are several company-specific characteristics examined as control variables and found to impact the board of directors characteristics and/or the accuracy of IPO earnings forecasts and they include company size, forecast horizon and leverage. These have been specifically mentioned in prior studies conducted by Firth and Smith (1992), Jelic et al. (1998), Ahmad-Zaluki \& Wan-Hussin (2010), and Firth et al. (2012).

\section{Data and Methodology}

The present study has its basis on IPO prospectuses and annual reports of such firms listed in the Bursa Malaysia Main Market for the period from January 2002 to February 29, 2012. During this span of years, new issues were reported on the Bursa Malaysia. The study selected the IPO companies based on the following conditions;

1. The IPOs prospectuses and annual reports for the examined years are available, and

2. IPO prospectuses contain relevant information on earnings forecasts.

The study did not include financial, close-end fund and real estate investment trust firms as they possess distinct regulatory requirements that govern their disclosure practices. The final sample consisted of 190 IPO companies following the exclusion of the mentioned firms.

The accuracy of earnings forecasts was measured using the absolute forecast error (AFER) and was obtained as the absolute value of actual earnings less the forecasted earnings, over forecasted earnings;

$A F E R_{i t}=\left|F E R_{i t}\right|$

$A F E R_{i t}=\left|\left(A E_{i t}-F E_{i t}\right)\right| /\left|F E_{i t}\right|$

Where:

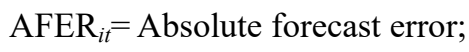

$\mathrm{AE}_{i t} \quad=$ Actual earnings of company $\mathrm{i}$ for the period $\mathrm{t}$;

$\mathrm{FE}_{i t} \quad=$ Forecasted earnings of company $\mathrm{i}$ for the period $\mathrm{t}$.

The factors influencing the accuracy of IPO management earnings forecasts were identified and determined using multivariate analysis. The AFER level was regressed on three variables relating to the board characteristics, and six control variables relating to signaling (high quality underwriter and auditor) and to company-specific characteristics, namely company size, forecast horizon and leverage. The linear regression was used as follows; 
$A F E R_{i t}=\beta_{0}+\beta_{1} B_{S S I Z E_{i t}}+\beta_{2}$ BIND $_{i t}+\beta_{3} D U A L I T Y_{i t}+\beta_{4} M O W N_{i t}+\beta_{5} U N D E R W_{i t}+\beta_{6} A U D_{i t}+\beta_{7} S_{I Z E_{i t}}+\beta_{8}$
$F H_{i t}+\beta_{9} L E V_{i t}+\varepsilon$

The major experimental variables of this study include board size, board independence and CEO duality. To begin with, board size (BSIZE) was measured by the total number of directors on the board following Ahmad-Zaluki \& Wan-Hussin (2010) and Ammer and Ahmad-Zaluki (2014). As for board independence (BIND), it was measured as the percentage of independent non-executive director on the board to the total board directors as employed in Bédard et al.'s (2008) study. Also, similar to Xie et al. (2003) and Bédard et al. (2008), this study measured CEO duality (DUALITY) as dummy variable " 1 " when the same person is positioned as CEO as well as the board chairman, and "0" otherwise.

In addition to the above measurements, underwriter's reputation (UNDERW) depicts the ringgit value of the underwritten shares by the underwriter deflated by the total ringgit value of the IPO samples and auditor quality (AUD) was measured as a dummy variable " 1 " if the auditor is from the Big 4, while "0" otherwise.

Moreover, management ownership (MOWN) is measured by the percentage of shares owned by the executive directors and company size (SIZE) was measured by the total assets at the IPO prospectus data. The study measured forecast horizon $(\mathrm{FH})$ as the number of months between the date of management forecast and the date of the end of the forecast period and finally, leverage (LEV) was depicted by total liabilities over total assets.

\section{Analysis and Findings}

\subsection{Descriptive Statistics}

The results of the descriptive statistics conducted on the variables (dependent, independent and control) are tabulated in the following table:

Table 1. Descriptive statistics of dependent, independent and control variables

\begin{tabular}{cccccc}
\hline Variables & Mean & Median & Std. & Minimum & Maximum \\
\hline AFER (\%) & 24.94 & 9.37 & 48.54 & 0.13 & 525.45 \\
BSIZE & 7.37 & 7.00 & 1.76 & 4.00 & 16.00 \\
BIND (\%) & 37.57 & 33.33 & 8.38 & 22.22 & 75.00 \\
DUALITY & 16.32 & - & - & - & - \\
MOWN (\%) & 11.76 & 4.15 & 15.58 & 0.00 & 66.94 \\
UNDERW (\%) & 19.05 & 10.45 & 19.18 & 0.13 & 49.11 \\
AUD (\%) & 54.74 & - & - & - & - \\
SIZE(RM million) & 350.11 & 101.19 & $1,402.58$ & 35.12 & $17,073.86$ \\
FH(months) & 7.71 & 7.00 & 3.01 & 3.00 & 14.00 \\
LEV (\%) & 51.04 & 47.83 & 23.89 & 3.86 & 150.48 \\
\hline
\end{tabular}

The results in the above table shows that absolute forecast error (AFER) obtained a mean (median) of 24.94\% (9.37\%). Studies of this caliber in the same context indicated the mean to be $54.91 \%$ (Jelic et al., 1998) and 23.76\% (Ahmad-Zaluki \& Wan-Hussin, 2010). Such percentage of accuracy in Malaysian IPO earnings forecasts is deemed to be unsatisfactory, as AFER should not deviate significantly from zero. Notwithstanding this fact, AFER in the current study compared to the past studies indicated development of the accuracy of earnings forecasts with the passing of years.

Moving on to the characteristics of the board - board size (BSIZE) was 7 for the whole sample, notably, the IPO firms had over four board of directors members. Board independence (BIND) showed an average of independent directors with a mean of $37.57 \%$ and median of $33.33 \%$. This is an indication that 164 IPO Malaysian firms (86\%) comply with the MCCG (2000) mandated recommendations, by having at least $1 / 3$ rd non-executive directors on their boards. This also means that insiders dominate the board composition of the IPO firms in Malaysia.

As for CEO duality (DUALITY), 31 IPO companies had it, with the mean being 16.32\%, reflecting a high adherence-level with the recommendation laid down by MCCG and the rarity of duality practiced in Malaysian IPOs. The proportion of management ownership (MOWN) varied from 0-66.94\%, with a mean of $11.76 \%$.

The IPO firms underwriter reputation (UNDERW) showed some share issues underwritten by the most reputable underwriters and the variable obtained a mean of $19.05 \%$. The IPO firms leaned towards Big 4 firms as the auditor choice, with $54.74 \%$ of the sample (104 companies) audited by the Big 4 . 
In light of the control variables, Table 1 shows the results of the descriptive statistics results. The IPO firms differed in size (SIZE), having an average of RM350.11 million. For forecast horizon (FH), the mean is 7.71 months (ranged from 3-14 months). Lastly, for leverage (LEV), gauged using the ratio of total debt to total asset (higher leverage means higher risk), the mean level is $51.04 \%$.

\subsection{Pairwise Correlation}

This study conducted correlation analysis to demonstrate the direction of the variables' relationships and provide a description of both their strength and significance. The Pearson correlation coefficients results between AFER (dependent variable) and the independent and control variables are tabulated in Table 2. It is clear from the table that no significant relationship was found between AFER and BSIZE, BIND, and DUALITY. The values of correlation coefficient should remain lower than 0.80 (for no multicollinearity issues) and because the highest correlation coefficient is 0.30 , no such issues was deemed to exist.

Table 2. Pearson correlation matrix

\begin{tabular}{|c|c|c|c|c|c|c|c|c|c|c|c|}
\hline & AFER & BSIZE & BIND & DUALITY & MOWN & UNDER & AUD & SIZE & AGE & FH & LEV \\
\hline AFER & 1 & & & & & & & & & & \\
\hline BSIZE & -0.044 & 1 & & & & & & & & & \\
\hline BIND & -0.093 & $-0.288^{* *}$ & 1 & & & & & & & & \\
\hline DUALITY & 0.089 & -0.127 & -0.007 & 1 & & & & & & & \\
\hline MOWN & 0.126 & -0.060 & -0.037 & $0.181^{*}$ & 1 & & & & & & \\
\hline UNDER & -0.107 & 0.073 & 0.089 & $-0.151^{*}$ & -0.090 & 1 & & & & & \\
\hline AUD & -0.077 & -0.004 & 0.041 & -0.066 & -0.132 & 0.128 & 1 & & & & \\
\hline SIZE & -0.010 & 0.072 & 0.122 & $-0.181^{*}$ & $-0.300^{* *}$ & $0.265^{* *}$ & $0.255^{* *}$ & 1 & & & \\
\hline FH & 0.100 & -0.047 & -0.099 & -0.075 & 0.058 & 0.038 & -0.041 & 0.023 & 0.077 & 1 & \\
\hline LEV & -0.077 & 0.039 & 0.070 & 0.113 & 0.027 & -0.038 & -0.128 & 0.107 & -0.062 & $-0.164^{*}$ & 1 \\
\hline
\end{tabular}

Significant at: $* * 0.05$ and $* 0.10$ levels employing two-tailed tests

\subsection{Multivariate Regression Analysis}

The results of the cross-sectional multivariate analysis conducted on the study variables are discussed in this section. Table 3 contains the detailed results, wherein which, board size (BSIZE) was found to be negatively and insignificantly related with AFER, indicating that hypothesis H1 is rejected. In other words, with the increase in the board of directors size, the level of earnings forecasts errors will decrease. This result may be attributed to more directors performing effective roles and decreasing information asymmetry between the investors and the company. The study findings are comparable to the prior studies of the same caliber in the same context that empirically found the influence of board size on the voluntary disclosure level (e.g., Wan-Hussin, 2009) as well as earnings management (e.g., Abdul Rahman \& Ali, 2006; Salleh \& Haat, 2014).

With regards to the relationship between board independence (BIND) and AFER, a negative relationship was found, which means independent directors do function to enhance the accuracy level - however, in this case, the BIND lacks significance and thus, hypothesis $\mathrm{H} 2$ is only partially supported. This finding deviates from the agency theory assumption that independent directors are efficient monitoring mechanism that oversees management activities. The theory also assumes that independent directors decrease uncertainty while supporting board effectiveness (Fama \& Jensen, 1983). This result may be related to the board independence existence in firms only in light of their adherence to the MCCG's mandate that $1 / 3 \mathrm{rd}$ of the board should be independent, and not of actual independence in management oversight.

Table 3. Multivariate analysis

\begin{tabular}{ccccc}
\hline & Expected Sign & Coefficient & $t$-stat & VIF \\
\hline BSIZE & + & -0.747 & -1.149 & 1.149 \\
BIND & - & -0.047 & -0.338 & 1.132 \\
DUALITY & + & -2.509 & -0.819 & 1.098 \\
MOWN & - & -0.076 & -1.025 & 1.113 \\
UNDERW & - & -0.126 & $-2.160^{* *}$ & 1.096 \\
AUD & - & -3.875 & $-1.697^{*}$ & 1.114 \\
SIZE & - & 2.269 & $1.813^{*}$ & 1.249 \\
FH & + & 0.533 & 1.400 & 1.062 \\
\hline
\end{tabular}




\begin{tabular}{cccc}
\hline LEV & + & 6.000 & 1.262 \\
Constant & -6.212 & -0.380 & \\
$n$ & 173 & \\
$R$-square $\%$ & 9.9 & \\
Adjusted $R$-square $\%$ & 4.9 & \\
$F$-value & $1.992 * *$
\end{tabular}

Multivariate outliers are recognized when the absolute values of the observations' studentized residuals equal to two or higher. Thus, by employing the studentized residuals test, seventeen IPOs have been excluded from the total sample. *,and ** indicates significance at the $10 \%$, and $5 \%$ levels for two-tailed tests.

As for CEO-chairman duality (DUALITY), it is found to have a negative relationship with AFER (refer to Table 3 ), but the relationship is insignificant, indicating that hypothesis $\mathrm{H} 3$ is rejected. It appears through the findings that IPO firms with separate CEO and chairman positions are not expected to issue accurate earnings forecasts, in that the agency theory's argument of separation of responsibilities is not supported. This is consistent with the result provided by Xing et al. (2019), which revealed that board secretaries with dual roles are more capable of accessing information and resources, which ultimately results in providing high-quality management earnings forecasts.

Table 3 also shows that management ownership (MOWN) has a negative and insignificant relationship with AFER, in that the higher the management ownership, the lower will be the earnings forecast error. This is in line with the argument of the agency theory, which states that management ownership is an efficient mechanism used to mitigate the management-shareholders agency conflict. Also, this is in line with Sosnowski and Wawryszuk-Misztal (2019), who revealed that higher management ownership leads to higher accuracy of forecasts.

Furthermore, in terms of underwriter's reputation (UNDERW), the results in Table 3 support a negative and statistically significant relationship with AFER, indicating that UNDERW leads to higher earnings forecasts accuracy. The auditor's quality (AUD) variable was found to have a negative significant relationship with AFER, which shows that reputable and quality auditors in Malaysia lead to better earnings forecasts accuracy.

Moving on to company size (SIZE), the result support a positive significant relationship with AFER, which shows that large-sized IPOs are likely to issue less accurate earnings forecasts in Malaysia. This result supports those reported by prior studies by Ahmad-Zaluki and Wan-Hussin (2010) in the Malaysian context and Firth and Smith (1992) in the case of New Zealand. With regards to forecast horizon, the relationship was found to be positive but insignificant. The argument is such that the longer the earnings forecasts period, the higher will be the uncertainty. Lastly, this study found a positive but insignificant relationship between leverage (LEV) and AFER, which means the higher the company debt, the higher will be the earnings risks.

\section{Conclusion}

This study aimed to present empirical evidence on the impact of corporate governance characteristic (board of directors) on the accuracy of IPO earnings forecasts. The study examined the relationship between board size, directors' independence and CEO duality on the accuracy of management earnings forecasts.

According to the obtained analysis results, the level of accuracy of earnings forecasts that IPO prospectuses published in Malaysia is unsatisfactory, which implies that IPOs management have to put in considerable effort in disclosing accurate earnings forecast. The findings in this study show that board size and CEO duality have a negative relationship with the earnings forecasts errors. That is, as the size of the board of directors increases, the level of earnings forecasts errors decrease. Further, this proposes that IPO companies that separate the position of $\mathrm{CEO}$ and chairman are less expected to issue accurate earnings forecasts. As for independence of the board, it was found to have a negative but insignificant relationship with the level of earnings forecast errors, which shows that the higher the independence of directors the lower will be the earnings forecast errors. This supports the agency theory which assumes independent directors to play a key role in monitoring management activities.

The study findings have implications to entities and individuals who are interested in maintaining the reliability and transparency of the financial statements. However, similar to other studies, the study has its limitations, the first being the limitation of sample to Malaysian firms. This necessitates caution in generalizing the findings to other stock markets in other countries, owing to the differences in the capital markets attributes.

\section{References}

Abbott, L. J., Park, Y., \& Parker, S. (2000). The effects of audit committee activity and independence on 
corporate fraud. Managerial Finance, 26(11), 55-68. https://doi.org/10.1108/03074350010766990

Abdul Rahman, R., \& Ali, F. H. M. (2006). Board, audit committee, culture and earnings management: Malaysian evidence. Managerial Auditing Journal, 21(7), 783-804. https://doi.org/10.1108/02686900610680549

Aharony, J., Lin, C. J., \& Loeb, M. P. (1993). Initial public offerings, accounting choices, and earnings management. Contemporary Accounting Research, 10(1), 61-81. https://doi.org/10.1111/j.1911-3846.1993.tb00382.x

Ahmad-Zaluki, N. A., \& Wan-Hussin, W. N. (2010). Corporate governance and earnings forecasts accuracy. Asian Review of Accounting, 18(1), 50-67. https://doi.org/10.1108/13217341011046006

Ajinkya, B., Bhojraj, S., \& Sengupta, P. (2005). The association between outside directors, institutional investors and the properties of management earnings forecasts. Journal of Accounting Research, 43(3), 343-376. https://doi.org/10.1111/j.1475-679x.2005.00174.x

Ammer, M. A., \& Alsahlawi, A. M. (2019). An empirical investigation into the impact of Shari'ah-compliant status and Muslim directorship on the accuracy of IPO management earnings forecasts. International Journal of Islamic and Middle Eastern Finance and Management, 12(1), 56-75. https://doi.org/10.1108/IMEFM-07-2017-0174

Ammer, M. A., \& Ahmad-Zaluki, N. A. (2014). Absolute forecast errors of earnings in Malaysian IPO prospectuses: the impact of ethnic diversity. Jurnal Teknologi, 68(3), 97-104. https://doi.org/10.11113/jt.v68.2954

Ammer, M. A., \& Ahmad-Zaluki, N. A. (2017). The effect of disclosure regulation on the bias and accuracy of management earnings forecasts in Malaysian IPO prospectuses. Journal of Financial Reporting and Accounting, 15(1), 59-77. https://doi.org/10.1108/JFRA-11-2015-0099

Beasley, M. S. (1996). An empirical analysis of the relation between the board of director composition and financial statement fraud. The Accounting Review, 71(10), 443-465.

Bédard, J., Coulombe, D., \& Courteau, L. (2008). Audit committee, underpricing of IPOs, and accuracy of management earnings forecasts. Corporate Governance: An International Review, 16(6), 519-535. https://doi.org/10.1111/j.1467-8683.2008.00708.x

Certo, S. T., Daily, C. M., \& Dalton, D. R. (2001). Signaling firm value through board structure: An investigation of initial public offerings. Entrepreneurship Theory and Practice, 26(2), 33-50. https://doi.org/10.1177/104225870102600202

Chapple, L., Dunstan, K., \& Truong, T. P. (2018). Corporate governance and management earnings forecast behaviour. Pacific Accounting Review, 30(2), 222-242. https://doi.org/10.1108/PAR-09-2016-0081

Cormier, D., Lapointe-Antunes, P., \& McConomy, B. J. (2014). Forecasts in IPO prospectuses: The effect of corporate governance on earnings management. Journal of Business Finance \& Accounting, 41(1-2), 100-127. https://doi.org/10.1111/jbfa. 12060

Fama, E. F., \& Jensen, M. C. (1983). Separation of ownership and control. The Journal of Law and Economics, 26(2), 301-325. https://doi.org/10.1086/467037

Fan, J. P., \& Wong, T. J. (2002). Corporate ownership structure and the informativeness of accounting earnings in East Asia. Journal of Accounting and Economics, 33(3), 401-425. https://doi.org/10.1016/S0165-4101(02)00047-2

Firth, M., \& Smith, A. (1992). The accuracy of profits forecasts in initial public offering prospectuses. Accounting and Business Research, 22(87), 239-247. https://doi.org/10.1080/00014788.1992.9729441

Firth, M., Gounopoulos, D., \& Pulm, J. (2012). IFRS adoption and management earnings forecasts of Australian IPOs. Working paper, EFMA-University of Barcelona. https://doi.org/10.2139/ssrn.2199034

Foerster, S. R., Sapp, S., \& Shi, Y. (2013). The impact of management earnings forecasts on firm risk and firm value. Retrieved from http://papers.ssrn.com/sol3/papers.cfm?abstract_id=2199587

Gounopoulos, D. (2011). Associations between management forecast accuracy and pricing of IPOs in Athens Stock Exchange. Multinational Finance Journal, 15(3-4), 235-272. https://doi.org/10.17578/15-3/4-4

Guo, R. E. J. I. N., Lev, B., \& Zhou, N. (2004). Competitive costs of disclosure by biotech IPOs. Journal of Accounting Research, 42(2), 319-355. https://doi.org/10.1111/j.1475-679X.2004.00140.x 
Hartnett, N. (2010). The value relevance of earnings forecast disclosures: An investigation of forecast attributes and signalling in the Australian IPO context. Applied Financial Economics, 20(23), 1819-1828. https://doi.org/10.1080/09603107.2010.526574

Hutagaol, Y., Warganegara, D. L., \& Wibisono, C. (2012). The accuracy of earnings forecast and post-IPO earnings management. Working paper. Retrieved from http://www.globalresearch.com.my/proceeding/ icmef2012_proceeding/015_162_ICMEF2012_Proceeding_PG0183_0197.pdf

Hutton, A. P., \& Stocken, P. C. (2010). Prior forecasting accuracy and investorreaction to management earnings forecasts. Working Paper. https://doi.org/10.2139/ssrn.817108

Jelic, R., Saadouni, B., \& Briston, R. (1998). The accuracy of earnings forecasts in IPO prospectuses on the Kuala Lumpur Stock Exchange. Accounting and Business Research, 29(1), 57-72. https://doi.org/10.1080/00014788.1998.9729566

Jensen, M. C., \& Meckling, W. H. (1976). Theory of the firm: Managerial behavior, agency costs and ownership structure. Journal of Financial Economics, 3(4), 305-360. https://doi.org/10.1016/0304-405X(76)90026-X

Jog, V., \& McConomy, B. J. (2003). Voluntary disclosure of management earnings forecasts in IPO prospectuses. Journal of Business Finance \& Accounting, 30(1-2), 125-168. https://doi.org/10.1111/1468-5957.00486

Karamanou, I., \& Vafeas, N. (2005). The association between corporate boards, audit committees, and management earnings forecasts: An empirical analysis. Journal of Accounting Research, 43(3), 453-486. https://doi.org/10.1111/j.1475-679X.2005.00177.x

Klein, A. (2002). Audit committee, board of director characteristics, and earnings management. Journal of Accounting and Economics, 33(3), 375-400. https://doi.org/10.1016/S0165-4101(02)00059-9

Mnif, A. (2010). Corporate governance and management earnings forecast quality: Evidence from French IPOs. Retrieved from http://halshs.archives-ouvertes.fr/halshs-00459171/en/

Saleh, N. M., Iskandar. T. M., \& Rahmat, M. M. (2005). Earnings management and board characteristics: Evidence from Malaysia. Jurnal Pengurusan, 24, 77-103. https://doi.org/10.17576/pengurusan-2005-24-04

Salleh, N. M. Z. N., \& Haat, M. H. C. (2014). Audit committee and earnings management: Pre and post MCCG. International Review of Management and Business Research, 3(1), 307-318.

Shin, H., \& Kim, S. (2019). The effect of corporate governance on earnings quality and market reaction to low quality earnings: Korean evidence. Sustainability, 11(102), 1-17. https://doi.org/10.3390/su11010102

Siagian, F., \& Tresnaningsih, E. (2011). The impact of independent directors and independent audit committees on earnings quality reported by Indonesian firms. Asian Review of Accounting, 19(3), 192-207. https://doi.org/10.1108/13217341111185128

Sosnowski, T., \& Wawryszuk-Misztal, A. (2019). Board characteristics and earnings forecasts accuracy in IPO prospectuses. International Journal of Management and Economics, 55(1), 1-15. https://doi.org/10.2478/ijme-2019-0003

Wan-Hussin, W. N. (2009). The impact of family-firm structure and board composition on corporate transparency: Evidence based on segment disclosures in Malaysia. The International Journal of Accounting, 44(4), 313-333. https://doi.org/10.1016/j.intacc.2009.09.003

Xie, B., Davidson, W. N., \& DaDalt, P. J. (2003). Earnings management and corporate governance: The role of the board and the audit committee. Journal of Corporate Finance, 9(3), 295-316. https://doi.org/10.1016/S0929-1199(02)00006-8

Xing, L., Duan, T., \& Hou, W. J. (2019). Do Board Secretaries Influence Management Earnings Forecasts? Journal of Business Ethics. 154(2), 537-574. https://doi.org/10.1007/s10551-017-3478-6

Yang, C.-H., \& Kao, H. S. (2007). The association between management earnings forecast errors and corporate governance structure in IPO firms. Retrieved from http://www.ntpu.edu.tw/ads/doc/96/9-1.pdf

\section{Copyrights}

Copyright for this article is retained by the author(s), with first publication rights granted to the journal.

This is an open-access article distributed under the terms and conditions of the Creative Commons Attribution license (http://creativecommons.org/licenses/by/4.0/). 